\title{
O MACHISMO NO BANCO DOS RÉUS \\ UMA ANÁLISE FEMINISTA CRÍTICA DA POLÍTICA CRIMINAL BRASILEIRA DE COMBATE À VIOLÊNCIA CONTRA A MULHER
}

\author{
MACHISMO IN THE DOCK \\ A CRITICAL FEMINIST ANALYSIS OF BRAZILIAN CRIMINAL POLICY \\ CONCERNING THE COMBAT OF VIOLENCE AGAINST WOMEN
}

\author{
Clara Maria Roman Borges* \\ Guilherme Brenner Lucchesi $^{* *}$
}

\begin{abstract}
RESUMO: o presente artigo tem por objetivo realizar uma análise crítica dos discursos feministas, que levaram recentemente à promulgação das leis brasileiras responsáveis por tornar mais severa a punição da violência contra a mulher, de modo a demonstrar como não conseguem escapar das armadilhas cognitivas estabelecidas pela dominação masculina naturalizada nas sociedades ocidentais e como têm servido ao desenvolvimento de uma biopolítica neoliberal.
\end{abstract}

PALAVRAS-CHAVE: Feminismo. Violência de gênero. Lei Maria da Penha. Feminicídio. Criminalização.

ABSTRACT: The aim of this article is to critically analyze the feminist discourse that led to the recent enactment of Brazilian laws that increased the penalties for violence against women, in order to demonstrate that they cannot escape the cognitive traps established by male domination naturalized in Western societies and how they have served the development of neoliberal biopolitics.

KEYWORDS: Feminism. Gender-based violence. Maria da Penha Act. Femicide. Criminalization.

\section{INTRODUÇÃO}

Sabe-se que o combate à violência contra a mulher é uma das preocupações contemporâneas, que se reflete em ações de movimentos sociais, em políticas estatais, nas discussões e pesquisas acadêmicas. Várias soluções têm sido propostas e algumas até implementadas na busca da diminuição dos índices desta violência que é reflexo da dominação masculina naturalizada nas sociedades ocidentais como a brasileira.

\footnotetext{
* Professora Associada de Direito Processual Penal no Curso de Graduação e no Programa de Pós-Graduação em Direito da Universidade Federal do Paraná. Professora de Direito Processual Penal na Universidade Positivo. Mestra e Doutora em Direito pela Universidade Federal do Paraná. E-mail: romanborges@uol.com.br

** Doutorando no Programa de Pós-Graduação em Direito da UFPR. Master of Laws (LL.M.) pela Cornell Law School (EUA). Especialista em Direito Penal e Criminologia pelo Instituto de Criminologia e Política Criminal. Professor Substituto do Núcleo de Prática Jurídica da UFPR. Advogado em Curitiba/PR. Habilitado para o exercício profissional da advocacia no estado de Nova York (EUA).E-mail: gblucchesi@gmail.com
} 
Contudo, as agressões perpetradas por questões de gênero são fenômenos complexos e certamente não serão evitadas por medidas pensadas dentro da ordem masculina que organiza nossas estruturas sociais. Até o momento, não se conseguiu escapar desta armadilha cognitiva, e tem-se buscado resolver o problema a partir da criminalização do homem agressor, que tem sido punido severamente, e, num segundo plano, tem se vitimizado a mulher com políticas estatais paternalistas de assistência à agredida; isto é, tem-se buscado soluções masculinas para um problema criado justamente pela dominação masculina.

Evidentemente, o presente ensaio não tem por objetivo apresentar respostas ao problema da violência contra a mulher, mas estabelecer uma crítica feminista e não exclusivamente criminológica $^{1}$ a este discurso e às políticas estatais que propõem a criminalização da violência contra a mulher. Noutras palavras, analisa criticamente a Lei Maria da Penha (BRASIL, 2006) e a Lei do Feminicídio (BRASIL, 2015), a partir de um aporte sociológico-filosófico, de modo a denunciar por que seus discursos simbolicamente reafirmam a dominação masculina na sociedade brasileira e por que protegem a família-empresa, necessária ao desenvolvimento da biopolítica neoliberal.

Para tanto, entendeu-se imprescindível rastrear o momento em que o movimento feminista assumiu a criminalização como solução para o problema da violência contra a mulher no Brasil, compreender o contexto histórico da virada de seu discurso pela igualdade de gênero para o discurso da punição do inimigo da igualdade de gênero, para demonstrar como isso se constituiu no jogo das relações de poder da sociedade brasileira.

Deste modo, pesquisaram-se documentos da primeira metade do século passado, que transcreviam os discursos das protagonistas de movimentos feministas responsáveis por importantes conquistas na garantia legal da igualdade de gênero no Brasil, em que pese a deficiência na efetivação dessas leis até os dias atuais. Além disso, investigaram-se as ações estatais que teriam contribuído para um hiato dos discursos feministas no cenário político oficial de nosso País entre 1950 e meados de 1970. Por fim, foram analisadas as principais reivindicações dos vários movimentos feministas, que ganharam voz nos processos legislativos ocorridos a partir de 1980 no Brasil e que se institucionalizaram com a participação ativa na definição das políticas estatais destinadas a assegurar a igualdade de gênero, com o objetivo de detectar o momento em que os discursos desses movimentos incorporaram um clamor por punição do homem agressor. Note-se

\footnotetext{
${ }^{1}$ Quanto às críticas criminológicas sobre a criminalização da violência contra a mulher é imprescindível ler as obras das criminólogas críticas: ANDRADE, 1997, e KARAM, 1996.
} 
que neste ponto da pesquisa não foi mais possível trabalhar com o discurso individualizado de determinadas feministas, por força da pluralização dos próprios movimentos feministas, e, por este motivo, optou-se por tratar dos discursos institucionalizados e expressos nas leis que tinham como alvo a violência contra a mulher.

Ademais, para compreender as bases destes discursos de combate à violência contra a mulher, entendeu-se necessário mapear os estudos acadêmicos que de alguma maneira permearam e fundamentaram esta decisão bélica de combater o homem-agressor a partir da criminalização de sua conduta na Lei Maria da Penha (BRASIL, 2006) e na Lei do Feminicídio (BRASIL, 2015). Neste momento da pesquisa, decidiu-se que a análise dos estudos feministas ficaria restrita àqueles que legitimaram e legitimam a existência da referida legislação, em que pese ter-se conhecimento de que os estudos feministas avançaram muito, principalmente com a problematização do conceito de gênero.

Por fim, a crítica a este discurso de criminalização da violência contra a mulher é realizada a partir de marcos sociológicos e filosóficos fornecidos por Pierre Bourdieu e Michel Foucault; o primeiro, escolhido pela sua relevante e famosa análise a respeito da dominação masculina, e o segundo, pela sua visão peculiar a respeito do neoliberalismo. A partir de ambos os autores, cujos pensamentos não são fundamentalmente incompatíveis, busca-se demonstrar como o discurso de combate à violência contra a mulher é inapto para subverter a cultura que sustenta a dominação masculina nas sociedades neoliberais.

\section{O DISCURSO FEMINISTA PELA IGUALDADE DE GÊNERO: A LUTA PELO DIREITO DE PARTICIPAÇÃO POLÍTICA E NO MERCADO DE TRABALHO}

No ano de 1919, a bióloga Bertha Lutz participou oficialmente, como representante brasileira, da Primeira Conferência do Conselho Feminino da Organização Internacional do Trabalho - OIT, em que foram aprovadas as recomendações de salário igual para homens e mulheres, bem como a criação de um serviço de inspeção para assegurar a aplicação das leis de proteção dos trabalhadores. Neste momento, pode-se dizer que iniciava no cenário político de nosso País uma efetiva atuação feminina no sentido de influenciar as ações estatais relacionadas à questão da igualdade de gênero (SAFFIOTI, 2013, p. 358).

Em 1922, esta pioneira do movimento feminista brasileiro foi também responsável pela fundação da Federação Brasileira pelo Progresso Feminino - FBPF, que trazia em seu estatuto os propósitos de elevar o nível educacional feminino, proteger as mães, garantir o trabalho e o desenvolvimento profissional feminino, assegurar às mulheres direitos políticos e estreitar laços 
com outros países americanos a fim de colaborar na manutenção da paz. Já nesta época, o movimento feminista tinha inúmeras vertentes, e Bertha Lutz representava aquela que se identificava com os ideais de estratos médios da população brasileira e visava à expansão da estrutura capitalista no Brasil para a abertura de novas vias à emancipação econômica feminina (SAFFIOTI, 2013, p. 378). Porém, não se pode deixar de mencionar que, paralelamente, o feminismo tinha sua face operária, com as anarquistas da "União das Costureiras, Chapeleiras e Classes anexas”, que chamavam atenção para a precária situação das mulheres nas fábricas.

Em que pese a luta incessante, somente em 1932 as mulheres sem distinção conquistaram seu direito de voto, com a alteração do Código Eleitoral pelo Governo Provisório de Getúlio Vargas (1930-1934), que não era um grande simpatizante das causas feministas, mas que precisava amenizar as pressões do período revolucionário. Ao que parece, depois da Lei Estadual de 1928 que assegurou o direito de voto e a elegibilidade sem distinção de sexos no Rio Grande do Norte -, do Manifesto Feminista da FBPF exigindo a igualdade de gênero no exercício dos direitos e deveres individuais, e da acolhida do direito ao voto sem distinção de sexo na pauta da reforma eleitoral defendida pelos revolucionários de 1930, o governo federal não viu outra saída senão assegurar o voto feminino (SAFFIOTI, 2013, p. 365).

Ainda neste mesmo ano, Bertha Lutz passou a integrar a comissão formada pelo Governo Provisório de Getúlio Vargas para elaboração do Anteprojeto da Constituição ${ }^{2}$, apesar de impedida de atuar na subcomissão responsável pela redação do texto constitucional, que pretensamente fundaria a segunda república. Em seus discursos de abertura dos trabalhos constituintes, ela deixou claro que tinha a missão de lucidamente continuar a luta por direitos individuais e sociais sem distinção de gênero, iniciada com o movimento que garantiu o direito feminino ao voto no mesmo ano (LUTZ, 1936). Ressalte-se que, nas palavras desta feminista, as mulheres não formavam apenas uma classe, mas a metade da população que trabalhava incessantemente no lar, sem qualquer reconhecimento, profissionalmente mal remunerada e cujo talento era constantemente frustrado quanto à possibilidade de desenvolvimento e expansão (LUTZ, 1936).

O mesmo tom igualitário se identifica nas suas propostas para o Anteprojeto de Constituição, publicadas sob o título “13 Princípios Básicos”, dentre as quais se destacam a abolição da penosa dupla jornada de trabalho da mulher proletária, “que cumpre pena dobrada, acrescentando ao horário de fábrica, o trabalho, sem horário medido, que desempenha no lar”; a

\footnotetext{
${ }^{2}$ Bertha Lutz não se elegeu deputada naquele ano - sua participação na Comissão foi como representante do movimento feminista. Entretanto, duas outras deputadas participaram da Assembleia Constituinte de 1934: Carlota Pereira de Queiroz e Almerinda Faria Gama (BANDEIRA; MELO, 2010, p. 17-18).
} 
aplicação de leis de proteção ao trabalho sem distinção de sexo e nacionalidade; a previsão de assistência à mulher grávida e do seu direito de ausentar-se do trabalho durante a gravidez sem perder o emprego e o ingresso das mulheres no cenário político com o objetivo de conservar a vida acima de qualquer propósito de luta e dissenção, contrariando as civilizações masculinas que não haviam encontrado solução alternativa à guerra para as suas contendas. Porém, dentre todas as propostas a mais ousada é a declaração de direitos civis, econômicos e políticos, sem qualquer distinção de gênero, classe ou nascimento (1933).

Em 1937, a deputada Bertha Lutz apresentou o Projeto do Estatuto da Mulher (PL 736/1937) à Câmara dos Deputados e, na exposição de motivos, apontou a necessidade de revogação da legislação vigente que conflitava com o texto da Constituição recém-outorgada, a qual garantira o direito de voto feminino e abrira espaço à investidura das mulheres nos cargos do governo.

Denunciava que a legislação vigente, a qual exigia a outorga marital para que a mulher pudesse exercer plenamente sua capacidade na vida civil, estava contaminada por vestígios dos ultrapassados institutos da manus marital e do pater familias do direito romano. Afirmava, ainda, que tais leis eram incompatíveis com o padrão de produção e consumo estabelecidos pela Revolução Industrial dos séculos XIX e XX, que impulsionaram as mulheres à busca da própria subsistência e da sua família. Como consta no texto de justificação do referido projeto, não seria mais admissível que as leis refletissem o "desejo instinctivo do homem de sequestrar a mulher para o seu uso e goso, mesmo quando incapaz de prover o seu sustento” (LUTZ, 1937).

Quanto ao aspecto penal da legislação criticada, enfatizava que era injusta e anacrônica, na medida em que criminalizava e estabelecia punições igualitárias a homens e mulheres, mas exigia uma dose maior de imoralidade para punir o adultério dos homens, ou, ainda, punia severamente a mãe infanticida, muitas vezes abandonada e doente, enquanto o pai gozava da mais completa impunidade. Além disso, Bertha Lutz observava que essas leis, elaboradas por homens, atribuíam exclusivamente à vítima de lenocínio a iniciativa para acusação, quando o crime fosse praticado pelo próprio cônjuge, afastando do Estado a responsabilidade pela proteção desta mulher escravizada (LUTZ, 1937).

Note-se que os discursos feministas analisados não tratam o homem como inimigo a ser combatido de forma violenta e, nesta esteira, não reivindicam políticas públicas de criminalização da violência de gênero. Em nenhum momento pautam o aumento de penas para os crimes praticados contra as mulheres - a única ponderação que trazem é a necessidade de um tratamento 
igualitário para a mulher prostituída por um desconhecido e para aquela que sofre a exploração do seu cônjuge, com a definição da acusação pública para ambos os casos.

Em que pesem as críticas tecidas contra essas feministas, que foram acusadas de importar ideias que não eram compatíveis com a sociedade brasileira e que não tinham por fundamento as verdadeiras relações sociais que inferiorizavam a mulher, não se pode negar que seu discurso foi imprescindível para demarcar o espaço de participação da mulher neste contexto conturbado da década de 30, bem como nos anos subsequentes. Em suma, a despeito da falta de compreensão do funcionamento opressor da sociedade capitalista em relação à mulher, o discurso de Bertha Lutz e suas companheiras foi imprescindível para despertar a consciência em relação ao domínio patriarcal no Brasil, bem como ensejar a promulgação de várias leis que buscavam estabelecer certa igualdade de gênero (SAFFIOTI, 2013, p. 368 et seq.).

Veja-se que, durante os anos que se seguiram ao governo provisório de Getúlio Vargas, algumas das propostas de Bertha Lutz se concretizaram em leis, tal como o Estatuto da Mulher Casada, promulgado em 1962, que modificava a condição de incapacidade civil da mulher casada. Contudo, é certo que se verifica um hiato no que se refere à participação do movimento feminista no processo legislativo que se estende de 1937 até o final da ditadura militar. Neste período, as feministas tiveram uma participação política importante, tanto que, em 1943, a legislação trabalhista finalmente assegurou a proteção à maternidade, mas, tal como todos os movimentos sociais, elas foram silenciadas no processo de concepção e elaboração das leis no Brasil.

Na década de 50, o movimento feminista se destacou nas ações da Federação de Mulheres do Brasil, que participou da greve dos 300 mil e da Passeata da Panela Vazia, lutando pelo aumento do salário mínimo e contra a carestia da vida, o que inclusive deu origem à Lei Delegada $n^{0} 4$, que conferia amplos poderes às autoridade públicas para controlar a oferta e o consumo de mercadorias e tornou necessária a criação da Superintendência Nacional do Abastecimento - SUNAB (BANDEIRA; MELO, 2010, p. 23).

No governo de Juscelino Kubitschek (1956-1961), as várias associações feministas tiveram seu funcionamento suspenso, porém, tal medida não foi suficiente para impedir a atuação clandestina desses grupos de mulheres que apoiavam as mães solteiras, ensinavam costura e outras atividades manuais que pudessem permitir o seu sustento, bem como ampliavam paulatinamente sua participação nos sindicatos.

A despeito da efetiva participação das mulheres da classe média na Marcha da Família com Deus pela Liberdade (série de manifestações contra a ameaça comunista e o Governo de Jango), a qual criou o substrato perfeito para a concretização do golpe de Estado pelos militares em 
1964, não se pode dizer que o movimento feminista empreendeu um retrocesso em sua caminhada para a construção de uma sociedade mais igualitária (SARTI, 1988, p. 42).

Note-se que, ao longo da ditadura militar, muitas mulheres participaram dos movimentos revolucionários e foram torturadas, castigadas justamente por não estarem em suas casas cuidando dos filhos e do marido, por terem sido consideradas avançadas demais e, por este motivo, associadas à prostituição, como consta de seus testemunhos transcritos nas obras "Direito à memória e à verdade: luta, substantivo feminino” (OJEDA; MERLINO, 2010), “Ex-presos políticos e a memória social da tortura no Paraná (1964-1978)” (CALCIOLARI; MONTEIRO, 2006), "Mulheres e militância: encontros e confrontos durante a ditadura militar" (GIANORDOLINASCIMENTO; TRINDADE; SANTOS, 2012) e Relatório Final da Comissão Nacional da Verdade (CNV, 2014).

Além disso, essas mulheres não só lutaram contra a opressão de um governo militar mas, também, pela igualdade de gênero dentro dos próprios movimentos revolucionários. Aliás, a militância das mulheres contra a ditadura nunca teve seu devido reconhecimento pelos próprios companheiros de luta - a maioria das mulheres que participou da resistência restou na invisibilidade e elas sempre foram consideradas “filha de”, “esposa de”, “namorada de” ou "irmã de” algum importante ativista; raramente sua atuação foi vista como decisiva na luta pela redemocratização do País, tal como ressaltado por Mirian Goldenberg (1997, p. 349-365).

Inclusive se verifica, nas lembranças e depoimentos dessas militantes, que, no tocante às relações de gênero, a cultura autoritária também estava presente nas organizações de esquerda, na medida em que "as mulheres, apenas por serem mulheres, independentemente de suas capacidades, eram impedidas de assumir postos de liderança e direção”. Também é preciso destacar que, no caso de ameaça de prisão pelos órgãos da repressão, as estratégias de fuga só existiam concretamente para os dirigentes, todos homens (GIANORDOLI-NASCIMENTO; TRINDADE; SANTOS, 2012, p. 19).

Apesar das inúmeras dificuldades enfrentadas no exílio, as mulheres perseguidas pelo governo militar fizeram várias reuniões para discutir a luta por seus direitos, sob a censura e reprovação dos homens exilados, na maioria das vezes seus companheiros, que viam no feminismo uma distração no movimento pelo fim da ditadura (PINTO, 2003). Em suma, o movimento feminista sobreviveu de várias maneiras e não deixou de pautar que a luta pelo direito das mulheres não deveria se subordinar ou ser eclipsada pelas lutas gerais do povo brasileiro (BANDEIRA; MELO, 2010, p. 25). 
Alguns autores chegam a afirmar que a tentativa dos militares em despolitizar e calar os cidadãos em relação aos direitos humanos, bem como o afastamento da mulher no que se refere à vida política, foram justamente os fatores que levaram ao fortalecimento do movimento feminista na década de 70, de modo a aproximá-lo do radicalismo dos movimentos ocorridos nos EUA e na Europa na década anterior e a permitir sua organização para reivindicar a anistia e a reabertura democrática (SOARES, 1998, p. 35). A conferência da ONU que estabeleceu 1975 como ano internacional da mulher serviu de estopim para a fundação de centros feministas em São Paulo, Rio de Janeiro e Paraná, que lutavam pela virada democrática (SARTI, 1988, p. 63).

Portanto, num contexto brasileiro de ausência de democracia, o feminismo não esmoreceu e, neste mesmo ano, sob o patrocínio da ONU e da Associação Brasileira de Imprensa, os grupos de mulheres e jornais feministas se multiplicaram na luta contra a supremacia masculina, a violência sexual e pelo direito ao prazer (BANDEIRA; MELO, 2010, p. 26).

Simultaneamente, organizavam-se associações femininas de bairros, clubes de mães ligados à Igreja Católica, associações profissionais e grupos sindicalizados para exigir melhores condições de trabalho, creche para os filhos e a redução da pobreza (SARTI, 1988, p. 64).

Na segunda metade dos anos 70 e no início dos anos 80, as reivindicações feministas se pluralizaram e a violência contra as mulheres começou a ganhar espaço na mídia, principalmente pela veiculação de notícias sobre casos que repercutiram na sociedade da época, tais como os homicídios de Ângela Diniz (1976) Maria Regina dos Santos Souza Rocha (1980) e Eloísa Ballesteros (1980) por seus companheiros (BANDEIRA; MELO, 2010, p. 26). A partir deste momento os tribunais brasileiros começaram, inclusive, a se tornar menos tolerantes em relação à tese da morte do cônjuge feminino por exercício da legítima defesa da honra do esposo e a discutir sobre o estupro no casamento (RAMOS, 2012).

O movimento feminista voltará a participar efetivamente das decisões políticas e do processo legislativo brasileiro em meados da década de 80 , com a redemocratização do País, o que coincide com o momento em que as mulheres passaram a se preocupar de forma mais evidente com a questão da violência e, principalmente, com os mecanismos necessários para combatê-la (SARTI, 1988, p. 42).

Em 1983, foram criados os primeiros Conselhos Estaduais dos Direitos das Mulheres, em São Paulo e Minas Gerais, e, dois anos depois, o Conselho Nacional dos Direitos da Mulher CNDM, aos quais foi atribuída a responsabilidade por elaborar e concretizar políticas públicas específicas sobre as questões específicas das mulheres. Já no primeiro ano de funcionamento o CNDM lançou uma campanha convocando as mulheres para participarem das discussões da 
Assembleia Constituinte, o que culminou com o atendimento de oitenta por cento das demandas das mulheres no texto constitucional promulgado em 1988 (BANDEIRA; MELO, 2010, p. 27).

Em 1985, por pressão do Conselho Estadual dos Direitos das Mulheres, a Secretaria de Segurança de São Paulo criou as Delegacias de Defesa da Mulher, que tinham por objetivo prestar um atendimento especializado às mulheres vítimas de estupro, de espancamento ou de qualquer outra espécie de violência, diminuindo-lhes o constrangimento da denúncia de crimes sexuais ou das agressões perpetradas por seus maridos e companheiros (SARTI, 1988, p. 46).

Note-se que da mesma maneira que se verifica o avanço do movimento das mulheres no sentido de consolidar sua institucionalização e de ampliar a sua participação nos aparelhos do Estado, também se percebem suas rupturas em razão da diversidade das demandas femininas e da divergência cada dia mais clara entre o movimento e o pensamento feminista. Assim, as mulheres vivenciam a dificuldade de se organizar em torno de uma pauta comum, e o combate à violência contra a mulher passa a ser o elemento de convergência entre os vários discursos feministas, que fundamentam tanto as práticas do movimento quanto às reflexões do pensamento feminista no Brasil.

\section{O PENSAMENTO FEMINISTA E A VIOLÊNCIA CONTRA A MULHER}

Segundo Cecília Macdowell Santos e Wânia Pasinato Izumino (2005), na segunda metade da década de 80 os estudos feministas se voltaram para as ações do Estado nas esferas de segurança pública e justiça, com intuito de combater a violência contra a mulher, concentrando-se na pesquisa das espécies de crimes denunciados pelas mulheres, nas características de seus agressores e na posição da mulher em relação a esta violência.

De acordo com tais autoras, uma análise desses trabalhos permite identificar três correntes teóricas utilizadas para explicar a violência contra a mulher: a primeira, denominada dominação masculina, tem como ponto de partida o pressuposto de que a violência contra as mulheres decorre da dominação exercida pelo homem sobre a mulher, que se encontra naturalizada e vem sendo reproduzida nas relações sociais; a segunda é chamada de dominação patriarcal, e se encontra influenciada pela perspectiva feminista e marxista, compreendendo a violência contra a mulher como fruto da dominação masculina engendrada pelo capitalismo e pelo racismo; a terceira é nominada como relacional, na medida em que concebe a violência como uma forma de comunicação entre homens e mulheres e um jogo no qual a mulher não é vítima, mas cúmplice (SANTOS; IZUMINO, 2005, p. 148). 
A corrente teórica denominada dominação masculina tem como principal referência a filósofa Marilena Chauí e seu artigo intitulado “Participando do Debate sobre Mulher e Violência” (1985), no qual defende ser a violência contra as mulheres fruto da reprodução social de uma ideologia que transforma diferenças entre homens e mulheres em desigualdades hierárquicas autorizadoras da dominação e opressão da mulher. Noutras palavras, a dominação da mulher ocorreria, neste sentido, com a disseminação desta ideologia que a objetifica e a silencia, tornando-a dependente passiva e sem capacidade de se autodeterminar. Neste contexto, a condição feminina, idealizada a partir da maternidade como fundante do papel social da mulher, é definida como inferior à condição masculina, o que em última instância acaba naturalizando uma superioridade do homem sobre a mulher e, consequentemente, a violência por ele perpetrada. Porém, é preciso reconhecer que isso não impede as mulheres de praticarem violência, pois, como instrumentos da dominação masculina, tornam-se cúmplices da violência que recebem e que praticam; isto é, as mulheres que sofrem violência perpetrada por seus companheiros são vítimas de dominação masculina e ao mesmo tempo cúmplices, quando reproduzem esta naturalização da violência para seus filhos (SANTOS; IZUMINO, 2005, p. 149).

A corrente teórica da dominação patriarcal, capitaneada por Heleieth Saffioti, funda-se numa perspectiva feminista e marxista do patriarcado e busca entender a dominação masculina na sociedade de classes. Segundo a autora, o sistema capitalista de produção não absorve a mão de obra potencial de todos os integrantes adultos da sociedade de classes e, por este motivo, estabelece o filtro da determinação das duas categorias do sexo (homem e mulher) para amenizar os conflitos gerados pela ordem social competitiva. Portanto, reproduzindo o mito culturalmente naturalizado da mulher reprodutora, socializadora dos imaturos e consequentemente inferior, na medida em que seu trabalho não gera mais valia, o sistema capitalista marginaliza grandes contingentes femininos da estrutura de classes, da estrutura de produção. Nas palavras da autora,

[...] fatores de ordem natural, tais como sexo e etnia, operam como válvulas de escape no sentido de um aliviamento simulado de tensões geradas pelo modo capitalista de produção; e no sentido, ainda, de desviar da estrutura de classes a atenção dos membros da sociedade, centrando-a nas características físicas que, involuntariamente, certas categorias sociais possuem (2013, p. 58-59).

Pode-se dizer que esta corrente sustenta que o patriarcado não resume a dominação da mulher, a submissão da mulher ao “poder do macho”, à disseminação de uma ideologia machista, mas esta também é um instrumento importante de exploração econômica que tem como principal beneficiário o homem branco, rico e adulto. Neste sentido, a violência contra a mulher seria fruto desta socialização machista conservada pelo sistema capitalista, desta relação de poder desigual 
entre homens e mulheres, que estabelece como destino natural das mulheres a sua submissão e exploração pelos homens, forçando-as muitas vezes a reproduzir o comportamento machista violento (SANTOS; IZUMINO, 2005, p. 150).

A corrente teórica relacional, que tem como marco o trabalho de Maria Filomena Gregori, buscou relativizar esta dimensão dominação-vitimização. Para a referida autora, “existe alguma coisa que recorta a questão violência contra a mulher que não está sendo considerada quando ela é lida apenas como ação criminosa e que exige punição (a leitura reafirma a dualidade agressor $x$ vítima)” (GREGORI, 1999, p. 166).

Segundo ela, para entender a violência contra a mulher não se pode pressupor uma dualidade maniqueísta entre vítima e algoz, associados respectivamente a uma passividade e a uma ação destruidora. Portanto, afirma que o casal é uma unidade culturalmente construída e definidora de condutas complementares entre os gêneros masculino e feminino, dentro da qual são conferidos às mulheres alguns atributos associados à natureza, tais como seus instintos, a feminilidade construída a partir de seu corpo, o que explica em parte a sua clausura no doméstico (no universo da reprodução), tornando-a ao mesmo tempo singular e indispensável. Assim, a mulher vive de forma ambígua - ora gosta de ser indispensável e ora se ressente da limitação de sua liberdade. Aliás, é justamente esta situação paradoxal que explica ora a vitimização da mulher pela limitação de sua liberdade e pela possibilidade de seu corpo frágil sofrer violência, ora a manipulação que promove de seus medos para mostrar-se indispensável para o homem que pode ser o seu agressor, fazendo-o se sentir culpado e pronto para cumprir o papel por ela esperado. Deste modo, é possível constatar que as mulheres, muitas vezes inclusive por medo, reproduzem e reforçam os papéis de gênero, cooperando na produção de sua falta de autonomia, com o objetivo de obtenção de proteção e prazer. Neste contexto, a violência passa a funcionar perversamente como uma linguagem entre os parceiros que mantém a unidade do casal, a partir da preservação de seus papéis (GREGORI, 1999, p. 166).

Note-se que para as duas primeiras correntes o tema da violência implica inevitavelmente uma vitimização da mulher e fornece o substrato perfeito para a criminalização do homem agressor. De acordo com a corrente chamada de dominação masculina, a violência contra a mulher seria fruto da disseminação de uma ideologia machista que torna a mulher frágil por sua maternidade, incapaz de se autodeterminar e assujeitada ao homem visto como superior, enquanto para a corrente da dominação patriarcal o sistema capitalista teria, a partir do mito da inferioridade feminina, produzido a exploração econômica da mulher, tornando-a submissa ao homem branco, rico e adulto. Em ambas identifica-se uma mulher vulnerável e inapta a reagir à violência do homem 
superior, levando-nos concluir que caberia ao Estado esta reação.

Obviamente, as respostas estatais para este problema são limitadas a políticas dirigidas ao combate de alguns dos fatores geradores desta violência, à assistência das vítimas e à criminalização do ofensor. Sem dúvida, a primeira medida é a mais eficaz, pois possui um caráter pedagógico e desconstrói, a partir da educação, a simbologia que sustenta a dominação masculina; porém, seus efeitos são produzidos lentamente, o que pode ser frustrante na sociedade contemporânea que busca respostas rápidas. Já a segunda é sempre necessária, na medida em que cabe ao Estado prestar assistência aos cidadãos em situação de perigo. Contudo, é apenas paliativa, uma vez que não é capaz de evitar a continuidade da agressão. A terceira medida, por sua vez, figura como uma resposta imediata à violência, aplacando o clamor vingativo da sociedade; contudo, é ineficaz em longo prazo, por força da comprovada falência do sistema penal na recuperação dos criminosos (FOUCAULT, 1994b). Porém, é preciso notar que nenhuma das políticas estatais seria capaz de pôr fim às práticas de poder que estabelecem uma normalização das relações entre homens e mulheres a partir de um discurso da superioridade masculina e da permissividade em relação à violência.

Quanto à terceira corrente, pode-se dizer que faz uma análise diferenciada da violência contra a mulher, pois considera a complexidade do fenômeno sem cair na armadilha maniqueísta da dominação-vitimização. Como exposto, defende que a mulher também é protagonista desta violência, contribui para sua perpetração, e nesta perspectiva permite afirmar que o ciclo vicioso das agressões não cessará com a criminalização do seu ofensor, mas depende de um empoderamento da mulher capaz de libertá-la deste ciclo escravizante, ao qual está submetida por ser a violência muitas vezes a única linguagem possível para se comunicar com aquele com quem coabita. Então, a partir desta vertente teórica feminista, seria viável pensar solução distinta da punição e do encarceramento do agressor para impedir a violência contra a mulher.

Aliás, na década de 90 surgiram outras correntes teóricas feministas, que forneceriam novos fundamentos para pensar a violência contra a mulher, principalmente a partir da problematização do conceito de gênero, entendido como construção social do masculino e do feminino e como categoria de análise das relações entre homens e mulheres. Inclusive, anos mais tarde, as feministas brasileiras (PINTO, 2010), influenciadas principalmente por Judith Butler (2003) e Beatriz Preciado (2010), ousariam a problematizar o conceito de sexo, que seria visto também como uma construção social, fruto das relações de poder e das práticas que o vinculam ao gênero por repetições discursivas e que estabelecem o padrão normalizador para a materialidade dos sujeitos homem/mulher heterossexuais. 
Deste modo, tornou-se mais complexa a compreensão da relação entre homens e mulheres e da violência perpetrada em seu âmbito, pois, contrariamente ao paradigma do patriarcado, que pressupõe papéis sociais rígidos e condicionados culturalmente pelas diferenças biológicas entre homem e mulher, a perspectiva de gênero desvela a diferença entre o social e o biológico, demonstrando como o feminino e o masculino são construídos socialmente nas relações de poder entre homens e mulheres (SANTOS; IZUMINO, 2005, p. 155).

Influenciadas incialmente pelos estudos de gênero da americana Joan W. Scott (1986), as feministas brasileiras passaram a pensar na violência contra a mulher como uma espécie de violência de gênero (SAFFIOTI; ALMEIDA, 1995). Nesta perspectiva, passaram a afirmar que a violência contra a mulher seria perpetrada por força das diferenças socialmente construídas entre homens e mulheres, que são reproduzidas nas relações desde a infância e estabelecem a dominação do masculino e o assujeitamento do feminino. Deste modo, o maniqueísmo de dois gêneros, fundado na heteronormalização que não admite um terceiro ou quarto, abriria espaço à constituição de um discurso e de práticas de poder que estabelecem símbolos para o masculino dominante e o feminino frágil de acordo com o contexto social analisado, verificando-se muitas vezes uma condescendência em relação à violência direcionada à manutenção desta ordem (SCOTT, 1986, p. 1067).

Com base nessas correntes teóricas feministas mais recentes, podemos concluir que uma ação efetiva para diminuir a violência contra a mulher deveria iniciar pelo questionamento das práticas de poder, que se exercem como discurso performativo normalizador, que impõem um padrão social de normalidade fundado no binômio de gênero masculino/feminino, na coerência entre esses gêneros e certas características sexuais biológicas, no desejo heterossexual, que relega à marginalização e todas as suas consequências aqueles que de alguma maneira não se encaixam ou subvertem este padrão.

\section{O MACHISMO NO BANCO DOS RÉUS: A INSTITUCIONALIZAÇÃO DOS DISCURSOS FEMINISTAS CRIMINALIZADORES NO COMBATE À VIOLÊNCIA CONTRA A MULHER}

Em que pese a proliferação dessas várias correntes teóricas feministas no Brasil, principalmente a partir do final do século passado, que problematizaram o conceito de gênero e sexo e seus efeitos opressivos, a institucionalização dos discursos feministas ocorreu por meio da adoção de políticas estatais fundadas na vitimização da mulher, que combatem a violência retirando da mulher a autonomia para impedi-la e criminalizando o agressor. 
Veja-se que o marco dessas políticas pode ser identificado na promulgação da conhecida Lei Maria da Penha (BRASIL, 2006), que excluiu os crimes praticados mediante violência doméstica contra a mulher do rol de infrações de menor potencial ofensivo, impedindo a realização de acordos civis extintivos da punibilidade, de suspensão condicional do processo e de transação penal; estabeleceu obstáculos à retratação da representação da vítima nos casos de lesões corporais leves; estabeleceu uma série de medidas cautelares de proteção à mulher em situação de violência, que vão desde o afastamento do suposto agressor do lar até a proibição de sua aproximação da vítima; impediu a aplicação de penas alternativas aos condenados por violência doméstica contra a mulher; tornou uma imposição o comparecimento do agressor em programa de recuperação e reeducação, bem como criou um juízo especializado para julgar estas questões.

Note-se que muitos foram os recursos linguísticos utilizados na elaboração do texto legal para romper com a tradição cultural da mulher considerada objeto da violência, tais como a substituição dos termos "mulheres vítimas de violência” por "mulheres em situação de violência doméstica”, ou a conceituação da violência de gênero como "violação dos direitos humanos das mulheres”, passível de ser perpetrada tanto por homens como por mulheres (CAMPOS; CARVALHO, p. 146 et seq.).

Entretanto, uma análise dos motivos que levaram à concepção da referida lei e das consequências de sua aplicação prática permite concluir que esta estratégia não foi suficiente para impedir que a mulher fosse tratada como objeto da violência, incapaz de ser protagonista nas ações dirigidas a cessar tal agressão, bem como para promover uma mudança das práticas de poder que naturalizam a dominação masculina e a violência de gênero. Em verdade, esta lei representa o que os penalistas chamam de “direito penal simbólico”, que criminaliza condutas e estabelece punições severas com o objetivo de tranquilizar a população, de demonstrar que o legislador atende as demandas sociais, ainda que as normas penais criadas estejam destinadas muitas vezes a não serem aplicadas e sua promulgação produza efeitos apenas simbólicos de segurança no imaginário social. (CANCIO MELIÁ, 2008, p. 57-60).

Sabe-se que a Lei 11.340/06 foi fruto de uma condenação do Brasil pela Corte Interamericana de Direitos Humanos da OEA, por omissão e negligência em relação à violência doméstica no caso de Maria da Penha Maia Fernandes, biofarmacêutica cearense que sofreu inúmeras agressões de seu ex-marido Marco Antonio Herredia Viveros, professor universitário. Em 1983, foi vítima da primeira tentativa de homicídio, ao receber um tiro nas costas enquanto dormia, o qual a deixou paraplégica, e a segunda tentativa de homicídio se deu quando o marido tentou eletrocutá-la. O primeiro julgamento só ocorreu oito anos após os crimes e, em 1991, a defesa 
conseguiu anulá-lo. Somente em 1996 Viveros foi condenado, mas recorreu e estendeu o processo por mais alguns anos. Então, em 1998, a Corte Interamericana recebeu a denúncia relativa ao caso de Maria da Penha, sendo que a condenação brasileira ocorreu em março de 2001.

Em suma, esta legislação tem como ato fundador a decisão de um caso de violência contra a mulher, e não a discussão social sobre políticas estatais para evitar a violência de gênero. Além disso, estabelece amplos poderes ao Estado para fazer cessar a violência, deixando a mulher alijada deste processo, bem como criminaliza e pune severamente o agressor.

No mesmo sentido caminhou a concepção da Lei $\mathrm{n}^{0} 13.104 / 15$, chamada Lei do Feminicídio (BRASIL, 2015), a qual tornou qualificada e, consequentemente, hedionda a prática de homicídio contra a mulher "por razões da condição do sexo feminino”, entendida como violência doméstica e familiar ou menosprezo discriminatório à condição de mulher, fixando pena de doze a trinta anos de reclusão. Também estabeleceu majorante de um terço até a metade da pena para o feminicídio cometido durante a gestação ou nos três meses após o parto, contra deficiente, menor de quatorze anos, maior de sessenta anos ou na presença de descendente ou ascendente da vítima, e, para progressão de regime, estabeleceu que não basta o cumprimento de um sexto de pena, sendo necessários dois quintos e, no caso de reincidência, três quintos.

Sem dúvida, é preciso reconhecer que essas legislações foram responsáveis por dar visibilidade à violência sofrida pela mulher no ambiente secreto de seu lar e nas relações privadas; neste aspecto representam inclusive conquistas feministas na luta pela igualdade de gênero, assim como demonstram a efetiva participação das mulheres no cenário político.

Desde a promulgação da Lei Maria da Penha tem-se notícia de que aumentaram os números de denúncias de violência contra a mulher, e a diminuição dessas agressões entrou na agenda dos poderes públicos, culminando com o Pacto Nacional de Enfrentamento da Violência contra a mulher (2011).

A última pesquisa publicada pelo Instituto de Pesquisa Econômica Aplicada (TD $\mathrm{n}^{0}$ $2048^{3}$ ), em março de 2015, que tinha por objetivo avaliar a efetividade de Lei Maria da Penha, demonstrou que desde a sua entrada em vigor ocorreu uma sensível diminuição dos índices de homicídios por questões de gênero em algumas regiões, onde se supõe que a ideologia patriarcal não seja tão forte e a subcultura permissiva em relação à violência contra a mulher menos arraigada. Também se verificou que essa diminuição dos índices de violência se deu onde os serviços de atendimento à mulher vítima de violência foram implantados.

\footnotetext{
${ }^{3}$ IPEA-TD n ${ }^{\circ}$ 2048, 2015.
} 
Contudo, é preciso igualmente reconhecer que essa legislação não foi capaz de estabelecer mudanças na cultura que sustenta a dominação masculina em nossa sociedade. Recentemente, noutra pesquisa, publicada em abril de 2014 pelo mesmo Instituto, com o objetivo de apurar as percepções brasileiras sobre temas afetos à violência contra a mulher ${ }^{4}$, constatou-se que 58\% de 3.810 entrevistados e entrevistadas concordaram que "se as mulheres soubessem se comportar, haveria menos estupros"; 68\% que "casos de violência dentro de casa devem ser discutidos somente entre membros da família”; 89\% que “a roupa suja deve se lavar em casa”; 82\% que "em briga de marido e mulher não se mete a colher”; 64\% que "os homens devem ser o cabeça do lar”; 79\% que “toda a mulher sonha em se casar”; 59\% que "uma mulher só se sente realizada quando tem filhos”; 52\% que "o casamento de homem com homem e mulher com mulher deve ser proibido"; 55\% que “tem mulher que é para casar e tem mulher que é para a cama”, e 64\% que "mulher que é agredida e continua com o parceiro gosta de apanhar”.

Note-se que apesar de mais de $90 \%$ dos entrevistados concordarem que "o homem que bate na esposa tem que ir para a cadeia”, não se pode deixar de notar que a cultura que perpetua a dominação masculina se encontra bastante naturalizada na população brasileira, que a ideia da existência natural de papéis estabelecidos para os gêneros masculino e feminino se encontra bastante sedimentada no imaginário social da nossa sociedade.

Neste sentido, Pierre Bourdieu (2014, p. 21) explica que

[...] a divisão entre os sexos parece estar na "ordem das coisas”, como se diz por vezes para falar do que é normal, natural, a ponto de ser inevitável: ela está presente, ao mesmo tempo, em estado objetivado nas coisas (na casa, por exemplo, cujas partes são todas “sexuadas”), em todo o mundo social e, em estado incorporado, nos corpos e nos habitus dos agentes, funcionando como sistemas de percepção, de pensamento e ação.

De acordo com o sociólogo francês, a força da ordem masculina não necessita de justificação e a visão androcêntrica se impõe neutra, sem necessidade de discursos para legitimá-la. Deste modo, a ordem social funciona como uma imensa máquina simbólica que reafirma constantemente a dominação masculina sobre a qual se encontra alicerçada, a qual se percebe na divisão sexual do trabalho, na distribuição das atividades designadas a cada um dos dois sexos, dos seus locais, momentos e instrumentos; bem como na estrutura do espaço, opondo os lugares públicos, como a assembleia ou o mercado, reservados aos homens, e os privados, como a casa, reservada as mulheres; ou ainda, no próprio lar, entre a parte masculina, como a sala de estar, e a

\footnotetext{
${ }^{4}$ IPEA-SIPS, 2014.
} 
parte feminina, como a cozinha (BOURDIEU, 2014, p. 24). ${ }^{5}$

Além disso, segundo Bourdieu, o mundo social também constrói o corpo como realidade sexuada e depositário de princípios de visão e de divisão sexualizantes; portanto, constrói a diferença entre os sexos biológicos, conformando-a a uma visão mítica do mundo, enraizada na relação arbitrária de dominação dos homens sobre as mulheres, o que serve de justificativa natural para a diferença socialmente construída entre os gêneros e, principalmente, para a divisão sexual do trabalho. Nas palavras do autor,

[...] a definição social dos órgãos sexuais, longe de ser um simples registro de propriedades naturais, diretamente expostas à percepção, é produto de uma construção efetuada à custa de uma série de escolhas orientadas, ou melhor, através da acentuação de certas diferenças, ou do obscurecimento de certas semelhanças (BOURDIEU, 2014, p. 29).

A representação da vagina como um falo invertido atende, desde a Idade Média, a oposições fundamentais entre o positivo e o negativo, permitindo perceber que o masculino passa a ser tomado como medida de todas as coisas e, nesta esteira, que o homem e a mulher são vistos como duas variantes, superior e inferior, da mesma fisiologia. Igualmente, nesta perspectiva, o ato sexual em si é concebido como uma forma de dominação, de posse, o que inclusive nos faz entender contemporaneamente a distância entre as expectativas prováveis dos homens e das mulheres em matéria de sexualidade, de relações amorosas e até da violência no âmbito conjugal:

[...] à diferença das mulheres, que estão socialmente preparadas para viver a sexualidade como uma experiência íntima e fortemente carregada de afetividade, que não inclui necessariamente a penetração, mas que pode incluir um amplo leque de atividades (falar, tocar, acariciar, abraçar, etc.), os rapazes tendem a "compartimentar" a sexualidade como um ato agressivo e sobretudo físico, de conquista orientada à penetração e ao orgasmo (BOURDIEU, 2014, p. 37).

No que se refere à divisão sexual do trabalho, a naturalização da dominação masculina se verifica nos postos oferecidos aos homens e às mulheres (médico/enfermeira; chefe/secretária, etc.), nas atitudes, nas roupas e nos penteados impostos às mulheres, que, ao participarem de um debate público, têm que lutar permanentemente para ter acesso à palavra e para manter a atenção, pois normalmente são interrompidas para que um homem possa, no seu lugar, falar algo mais inteligente; e, quando não aceitam a interrupção, imediatamente são tomadas como histéricas (BOURDIEU, 2014, p. 87).

No âmbito familiar e escolar, as mulheres constantemente ouvem que são mais frágeis, que as carreiras científicas são mais fáceis para os meninos, que devem optar por uma profissão que se

\footnotetext{
${ }^{5}$ Sobre este tema: SPAIN, 1992.
} 
compatibilize com a maternidade, e são advertidas constantemente de que sua autonomia pessoal e independência intelectual as aproximará do agir masculino e as afastará dos atributos da feminilidade e das “vantagens” de ser mulher, de gozar a proteção dos homens. Desta forma, paradoxalmente, as mulheres que subvertem sua feminilidade, aproximando-se do masculino e do poder (mulheres que ocupam cargos de diretoria, chefia, etc.) estão submetidas a um menor sucesso na ordem doméstica (divórcio, casamento tardio, celibato, dificuldades com os filhos), porque seu afastamento do lar para investimento profissional não é socialmente aceito e respaldado pela colaboração da família (BOURDIEU, 2014).

Neste contexto, a violência física contra a mulher figura como demonstração da dominação masculina em estado puro, pois significa o momento culminante da afirmação da virilidade, fundante da superioridade do homem no discurso da construção social dos sexos, o que não é muito tolerado, já que denuncia o assujeitamento feminino e desta maneira coloca em risco a manutenção da ordem masculina. Ao contrário da violência psicológica, sub-reptícia, tolerada e eficaz para estabelecer a submissão, pois parte do pressuposto que

[...] os dominados aplicam àquilo que os domina esquemas que são produto da dominação, ou, em outros termos, quando seus pensamentos e suas percepções estão estruturados de conformidade com as estruturas mesmas da relação da dominação que lhes é imposta, seus atos de conhecimento são, inevitavelmente, atos de reconhecimento, de submissão (BOURDIEU, 2014, p. 27).

Diante deste quadro complexo da dominação masculina, que permeia estruturas sociais objetivas e estruturas cognitivas, pode-se imaginar por que as leis anteriormente analisadas, que criminalizam a violência de gênero, não foram eficazes na diminuição dos índices de agressões perpetradas por homens contra mulheres ou na alteração das percepções sociais machistas no Brasil, conforme constatado nas pesquisas citadas.

Ora, ao colocarem o machismo no banco dos réus, as feministas apresentaram soluções masculinas para a violência de gênero, pois acabaram vitimizando e fragilizando ainda mais as mulheres, bem como estabeleceram uma violência maior aos agressores do que a por eles perpetrada; afinal tem-se conhecimento dos rituais estigmatizantes do processo penal, da falência do sistema penal brasileiro, das condições subumanas do cárcere a que são submetidos os condenados à reclusão em regime fechado.

Em suma, em que pese a conquista política representada pela Lei Maria da Penha (BRASIL, 2006) e pela Lei do Feminicídio (BRASIL, 2015), as feministas não conseguiram escapar da armadilha revelada por Pierre Bourdieu (2014, p. 17), decorrente do fato de que, como homens e mulheres incluídos numa sociedade patriarcal, incorporamos esquemas inconscientes de 
percepção e de apreciação das estruturas históricas de ordem masculina, o que nos leva a pensar a dominação masculina e formas de subvertê-la a partir de modos de pensamento que são produto da própria dominação.

Sem dúvida, é uma tarefa hercúlea pensar soluções para a violência de gênero que escapem à ordem masculina; portanto, os exercícios reflexivos não devem abrir mão dos instrumentos sociológicos e filosóficos para o questionamento das práticas de poder que mantêm a dominação dos homens sobre as mulheres. Por este motivo, vimos como necessária a realização desta breve análise de como se concretiza o poder simbólico do masculino para compreender como se engendra a dominação masculina nas práticas sociais e familiares cotidianas, e por que o discurso de criminalização da violência contra a mulher reforça as estruturas desta dominação (BOURDIEU, 1989). Contudo, acredita-se ser igualmente essencial compreender quais os fundamentos políticos subjacentes deste discurso de criminalização da violência contra a mulher no contexto da sociedade marcada por uma biopolítica neoliberal. Por este motivo, pede-se licença a Pierre Bourdieu, para pensar com Michel Foucault.

\section{O HOMEM INIMIGO EM TEMPOS DE BIOPOLÍTICA NEOLIBERAL}

Conforme já analisado em artigo anterior pela autora, com base nos escritos de Michel Foucault e sua microfísica do poder (BORGES, 2014), nos séculos XVIII e XIX, com a expansão do mercado e os consequentes movimentos migratórios responsáveis por incrementar as multiplicidades e pluralidades da população, as sociedades ocidentais assistiram ao (res)surgimento dos biopoderes, isto é, de práticas de poder que se apropriaram da vida para o governo deste novo corpo social heterogêneo (AGAMBEN, 2007, p. 14).

Nos termos da tese foucaultiana, esta nova mecânica de poder realizou a estatização do biológico, pervertendo por completo a ideia de um poder fundado na soberania, de um poder exercido exclusivamente pelo Estado/soberano sobre a vida e a morte de seus súditos. Paradoxalmente, de acordo com a teoria da soberania caberia ao Estado/soberano decidir, a partir do seu poder de matar, quem tem direito de estar vivo, o que demonstra a dissimetria no exercício deste poder, que não faz viver ou morrer, nem deixa viver ou morrer, mas faz morrer e deixa viver. O soberano inclusive poderia pedir aos súditos, durante a guerra, que, em defesa do Estado, expusessem sua vida a perigo, indiretamente exercendo, portanto, o seu poder de morte para defender-se dos inimigos. Assim, neste panorama da soberania, o poder de matar do soberano conteria o poder de vida e de morte dos súditos, ou seja, “é porque o soberano pode matar que ele 
exerce seu direito sobre a vida” (FOUCAULT, 1999, p. 287).

Então, quando surgiram os biopoderes e uma nova forma de se poder investir sobre a vida, este poder soberano de fazer morrer ou deixar viver não foi eclipsado, mas perpassado, penetrado de maneira a se transformar num poder de fazer viver e de deixar morrer. Esta nova tecnologia de poder não apagou, igualmente, as práticas de poder disciplinar, essenciais para o desenvolvimento do capitalismo industrial nos séculos XVI e XVII; contudo, não agiria mais sobre o corpo individual de maneira a distribuí-lo, organizá-lo, controlá-lo e torná-lo mais útil - o seu alvo seria a multiplicidade dos homens, a massa global, que deveria ser governada por meio da regulamentação de seus processos de vida, como o nascimento, a morte, a produção, as doenças, a sexualidade (FOUCAULT, 1994a, p. 605, v. III).

Nas palavras do filósofo francês, “depois da anátomo-política do corpo humano, instaurada no decorrer do século XVIII, vemos aparecer, no fim do mesmo século, algo que já não é uma anátomo-política do corpo humano, mas que eu chamaria de uma 'biopolítica’ da espécie humana” (FOUCAULT, 1999, p. 289).

Assim, a biopolítica se estabeleceu, controlando os processos de natalidade, mortalidade, longevidade e o modo de vida do ser humano, examinando, medindo estatisticamente esses fenômenos, para, num segundo momento, constituir saberes capazes de intervir diretamente sobre eles, regulamentando-os e, consequentemente, normalizando as grandes populações para governálas.

Note-se que a partir do século XVIII foram feitas observações sobre a natalidade e as endemias, verificando-se o surgimento de uma medicina dirigida à higiene pública, que deveria coordenar tratamentos médicos, centralizar informações, realizar campanhas de conscientização da população e promover a sua medicalização. Além disso, a biopolítica incidiu sobre os fenômenos que por acidente ou natureza relegam os indivíduos para fora do campo de atividade, de capacidade, tais como as anomalias, a velhice e mutilações, realizando uma regulamentação por meio de mecanismos racionais de assistência, seguro, poupança, previdência (FOUCAULT, 1999, p. 291).

Noutros termos, a biopolítica realizou uma intervenção em nível global ou populacional, mapeando os fenômenos da vida humana, estabelecendo um padrão de normalidade para esta vida e exercendo o poder de fazer viver (FOUCAULT, 1999, p. 294). Não por outro motivo, esta nova tecnologia de poder é percebida por seu cuidado evidente com a vida e pela progressiva desqualificação da morte. Neste sentido, desde o século XVIII verifica-se que as sociedades ocidentais promoveram uma progressiva desritualização da morte, o fim dos velórios prestigiados e brilhantes, bem como o estabelecimento de eventos privados, simplórios e breves, preocupando-se 
exacerbadamente com a vida útil, digna de ser vivida, ou com o fazer viver ${ }^{6}$ (AGAMBEN, 2007).

Como referido, a biopolítica como tecnologia regulamentadora não substituiu a tecnologia disciplinar, necessária ao desenvolvimento do capitalismo industrial, mas passou a coexistir com ela e a se sobrepor de forma a diagramar todo o corpo social com suas práticas, articulando-se a partir da norma que passa a se aplicar tanto ao corpo quanto à população. A norma é vista pelo filósofo francês como "uma maneira do grupo se dotar de uma medida comum segundo um rigoroso princípio de auto-referência, sem recurso a nenhuma exterioridade, quer seja a de uma idéia, quer a de um objeto” (EWALD, 1993, p. 108). A norma é uma medida deduzida da curva de normalidades de certo corpo social por meio de estatísticas e medições da população, é um critério que servirá para gerir essa multiplicidade de indivíduos, governá-la e dirigi-la, estabelecendo como deve viver, decidindo desta maneira quem se deve fazer viver e quem se deve deixar morrer.

Neste contexto, de articulação das disciplinas e dos biopoderes, o sexo passou a fazer parte da política, de um lado como elemento de disciplina dos corpos, adestramento, ajustamento, economia das energias, distribuição de forças, e de outro, como elemento de regulação das populações, dando lugar a vigilâncias infinitesimais e constantes, a exames médicos e psicológicos, bem como a medidas maciças, a estatísticas, a intervenções sobre todo o corpo social. Segundo Michel Foucault (1988, p. 159 et seq.), nos últimos dois séculos a política avançou em quatro grandes linhas de ataque. Por meio da norma estabeleceu a regulamentação da sexualização da criança, feita sob forma de campanha pela saúde e futuro da espécie humana; a histerização das mulheres, permitindo a medicalização minuciosa de seu corpo e sexo em nome da responsabilidade da maternidade e do futuro da família; e o disciplinamento dos corpos, no controle da natalidade e na psiquiatrização das perversões, com o objetivo de assegurar a vida da população.

Veja-se que a norma não se refere ao sistema jurídico da lei, que está sempre armada e cuja arma mais poderosa é a morte (seja física ou social) aos que a transgridem; ela regulamenta, estabelece uma medida comum, um perfil, que separa os indivíduos em "normais” (no que se refere à sexualidade estabelece o binário homem/mulher heterossexual) e “anormais” (aqueles que devem ser corrigidos, devem ser normalizados e até deixados para morrer) (FONSECA, 2002, p. 180).

Ressalte-se que a separação entre normais e anormais não situa estes fora do critério de sua distinção; ao contrário, o anormal tem a mesma natureza do normal, e a única diferença diz respeito à posição que ocupa em relação à norma. Aliás, em nome da verdade estabelecida pela norma se

\footnotetext{
${ }^{6}$ Esta preocupação do biopoder com o fazer viver não o impede de causar a morte, caso esta seja necessária para garantir a vida da população. Assim se justificam as guerras, o racismo, etc. Sobre o assunto, ver: FOUCAULT, 1999, p. 49-73 e p. 285-315.
} 
conduzem as populações, condiciona-se seu comportamento de massa a partir das conhecidas técnicas de pastoreio que vicejaram na Idade Média, no seio da Igreja, para guiar os rebanhos de fiéis (FOUCAULT, 1998).

Por fim, a biopolítica, levada ao seu extremo, não somente deixa morrer os anormais, mas faz morrer os inimigos, aqueles que são perigosos e ameaçam a vida da população (FOUCAULT, 2008b). Neste momento, explica-se o racismo ou, como nomina Agamben, a tanatopolítica (2007), que, simplificadamente, deixa de ser a expressão do ódio entre raças ou religiões, mas passa a servir como justificativa legítima para a implementação da ação mortífera dos Estados (DUARTE, 2009, p. 42).

A partir desta análise é possível explicar o nazismo, que tratava de exterminar, por meio do aniquilamento, raças supostamente inferiores, inclusive os homossexuais, sob o argumento de que colocavam em perigo a raça ariana; ou ainda, os motivos que levam a sociedade brasileira a relegar a "ralé” à morte pela polícia nas periferias das cidades, nos precários hospitais públicos ou nos cárceres desumanos de nosso País (SOUZA, 2011).

Aliás, sobre esta questão Giorgio Agamben (2007, p. 150) completa que

[...] o Reich nacional-socialista assinala o momento em que a integração entre medicina e política, que é uma das características essenciais da biopolítica moderna, começa a assumir a sua forma consumada. Isto implica que a decisão soberana sobre a vida se desloque, de motivações e âmbitos estritamente políticos, para um terreno mais ambíguo, no qual o médico e o soberano parecem trocar seus papéis.

Note-se que nesta sociedade normalizadora, marcada pela biopolítica, desenvolve-se um controle quase absoluto das populações, para governá-las e fazê-las viver, levando alguns autores a chamá-la de sociedade de controle (DELEUZE, 1992), que, na contemporaneidade, torna-se peçachave para o desenvolvimento do neoliberalismo.

Michel Foucault tem uma visão peculiar sobre o neoliberalismo, muito menos apocalíptica do que aquelas que circulam no universo da literatura jurídica, nas quais o mercado se expande a níveis inimagináveis, sem qualquer intervenção estatal, promovendo exclusão próxima da insuportabilidade, amenizada pelo aparato penal estatal que neutraliza aqueles que não consomem e que buscam violentamente sua inserção social.

Segundo ele, o neoliberalismo não tem, como o liberalismo clássico, o propósito de estabelecer um espaço livre para o desenvolvimento e a autorregulação do mercado na sociedade política, mas sim a projeção dos princípios formais de uma economia de mercado numa arte geral de governar. Isto significa que o neoliberalismo está distante do laissez-faire e demanda uma vigilância e intervenção permanente do Estado, que passa a funcionar de acordo com os princípios 
formais da economia de mercado (FOUCAULT, 2008a, p. 201).

Assim, para o neoliberalismo as relações sociais não são mais lidas como relações mercantis, de troca de mercadorias, tal como aventava o liberalismo clássico, mas como empresariais, concorrenciais (FOUCAULT, 2008a, p. 337). Neste sentido, a família não é mais vista exclusivamente como um espaço de trocas mercantis e acumulação de patrimônio, mas como uma área de produção de capital humano, já que a mãe investe seu tempo, seus cuidados e seu afeto para que o filho se torne adulto e produza renda, um salário. Deste modo, é possível compreender por que a família de maior renda passa a ter menos filhos, pois possui um capital humano elevado e tem como projeto econômico transmitir aos filhos um capital humano tão elevado quanto o seu, o que exige um investimento pesado na educação, na alimentação e saúde dos filhos, algo inviável em famílias numerosas. O grande problema é que nesse contexto o filho passa a ser o grande investimento familiar e, por este motivo, torna-se alvo de pesada carga de responsabilidades, o que acaba tornando a infância uma fase angustiada e, consequentemente, medicamentalizada (FOUCAULT, 2008a, p. 335-336).

No que se refere ao aspecto político, enquanto o liberalismo smithiano se definia pela delimitação de um espaço livre para que o mercado se desenvolvesse conforme mecanismos “naturais” e espontâneos, os quais estabeleciam um padrão de verdade que possibilitava discernir sobre as práticas governamentais corretas e incorretas, o neoliberalismo propunha novas questões a essas práticas, na medida em que a grade econômica permitiria testar a ação governamental, verificar sua validade, permitindo “objetar à atividade do poder público seus abusos, seus excessos, suas inutilidades, seus gastos pletóricos” (FOUCAULT, 2008a, p. 338). Deste modo, a governamentalidade passa a ser alvo de uma cínica crítica mercantil, não mais exclusivamente política ou jurídica, e diante dela se rearranja, aperfeiçoa-se e mantém o desenvolvimento do neoliberalismo; em termos foucaultianos, funda-se uma espécie de tribunal econômico permanente para julgar o governo e aperfeiçoá-lo.

Em relação ao indivíduo, o neoliberalismo produziu liberdades que nem sequer eram imaginadas, as quais inclusive não se encontram mais no espaço negativo de intervenção do Estado, como ocorre no liberalismo, mas que ao mesmo tempo são controladas para assegurar o governo e a vida da população. Portanto, ao criar inúmeras liberdades, o neoliberalismo também destruiu outras, estabelecendo um número limitado de possibilidades para gozá-las, proporcionando a estranha sensação de que em tempo algum se foi tão livre e ao mesmo tempo de que toda esta liberdade se encontra tão condicionada, tão normalizada. Numa análise de gênero, as mulheres nunca foram tão livres na expressão de sua sexualidade, para concorrer no mercado de trabalho e para projetar sua 
vida, desde que para isso não abram mão do projeto e do bom andamento da empresa familiar (FOUCAULT, 2008a, p. 86).

Por fim, no que se refere aos problemas da criminalidade e do funcionamento da justiça penal, que interessam sobremaneira ao tema ora analisado, o neoliberalismo propôs a intervenção no mercado do crime em detrimento da solução utilitarista-legalista apresentada pelos reformadores do século XVIII ${ }^{7}$.

Note-se que a crítica dos reformadores, fundada numa racionalidade econômica, incidia sobre o custo da delinquência, da prática judiciária tal como funcionava, sobre a ineficácia do sistema punitivo de suplícios e banimentos, e tinha como objetivo sustentar o projeto de um sistema penal com menor dispêndio. Nesse sentido, entendiam que a lei poderia ser a resposta mais econômica e eficaz para a punição das condutas nocivas às relações sociais, e por este motivo defenderam que o crime fosse definido como uma infração à lei, a qual estabeleceria as penas de acordo com a sua gravidade, cabendo aos tribunais aplicar esta pena, prevista na lei, ao crime ocorrido, após sua comprovação e de acordo com sua gravidade. Tratava-se de uma mecânica simplificada, óbvia, menos onerosa e mais eficiente para eliminar condutas nocivas da sociedade (FOUCAULT, 2008a, p. 341).

No entanto, esta nova economia do crime era paradoxal, na medida em que, por um lado, a lei buscava sancionar exclusivamente as condutas, e não os indivíduos, pelas suas qualidades pessoais, e, por outro lado, essa mesma lei se justificava pelo propósito de punir, corrigir os indivíduos, dando exemplo aos demais. Esta contradição explica, inclusive, a tendência interna do sistema penal, que, ao se aproximar de uma modulação cada vez mais individualizante da aplicação da lei penal, passa a problematizar psicologicamente, sociologicamente e antropologicamente aquele a quem se aplica a lei (FOUCAULT, 2008a, p. 341).

Por este motivo, no século XIX, o homo penalis se transforma no homo criminalis, provocando uma substituição da mecânica econômica da lei por uma inflação de conhecimentos, uma "inflação de discursos, uma multiplicação de instâncias, das instituições, dos elementos de decisão, e toda a parasitagem da sentença em nome da lei por medidas individualizantes em termos de norma” (FOUCAULT, 2008a, p. 342). Neste momento, consagra-se a escola etiológica ou positivista do direito penal, que tem Cesare Lombroso como autor mais conhecido (LOMBROSO, 2013).

Assim, é possível concluir que essas mudanças, ocorridas durante os séculos XVIII e XIX,

\footnotetext{
${ }^{7}$ Ver: BECCARIA, 2005, e BENTHAM, 2000.
} 
denotam que a organização do sistema penal a partir de uma racionalidade econômica levou inevitavelmente à concretização de um direito penal do autor, e não do fato, como se pretendia, fazendo com que a punição se concretizasse com a eliminação, o isolamento ou o tratamento daqueles indivíduos considerados perigosos e indesejáveis numa dada sociedade (ZAFFARONI, 2007, p. 11).

Como mencionado, os neoliberais buscam superar este paradoxo criado por este projeto em que a utilidade toma forma jurídica e o direito se constrói a partir do cálculo de utilidade, e, para tanto, problematizaram o crime exclusivamente no âmbito econômico e a partir da figura do homo oeconomicus (BECKER, 1968). Deste modo, o crime passou a ser toda a ação que faz o indivíduo correr risco de ser condenado a um pena, isto é, toda a ação que pode ser economicamente útil ou não ao indivíduo, considerando o risco da condenação a uma pena, a qual será governamentalizada pelo Estado por meio do mesmo cálculo de utilidade econômica.

Isso significa que a análise neoliberal do crime não se preocupa com os atos criminosos e a sua correção, mas com o indivíduo que busca lucrar com o crime e que corre risco de ser condenado, com o custo de sua condenação, com o risco de perda econômica que pode ser infligida por um sistema penal. Nesta perspectiva, o Estado passa a se concentrar em políticas para intervir no mercado do crime, para controlar a oferta do crime; passa a se preocupar com quais delitos devem ser permitidos, com quais delinquentes devem ser punidos e, principalmente, com as ações que oferecem perigo ao seu desenvolvimento econômico e ao desenvolvimento do mercado (FOUCAULT, 2008a, p. 350 et seq.).

Note-se que o sistema penal brasileiro, em seus aspectos formais ou legais, encontra-se marcado pela racionalidade econômica paradoxal do direito penal dos reformadores, destinado a punir atos, mas que se justifica pelo propósito de corrigir indivíduos. Contudo, em suas práticas, deixa claro, sem as máscaras das funções preventivas da pena, a preocupação com o mercado do crime, com os crimes que devem ser tolerados, com os delinquentes que devem ser punidos, com as ações que ameaçam o desenvolvimento do mercado.

Aliás, a política de criminalização da violência contra a mulher segue esta lógica na legislação brasileira, na medida em que estabelece, de um lado, penas cada vez mais severas ao homem agressor, sob o pretexto de inibir a prática de novas agressões e de corrigi-lo moralmente, e, de outro, um controle sobre ele, com medidas restritivas que o denunciam como verdadeira ameaça à família-empresa, ou, ainda, submetem-no ao cárcere para deixá-lo morrer.

Enfim, numa perspectiva da biopolítica neoliberal, sabe-se que o trabalho da mulher passou a ser essencial, não só na família-empresa, mas no que se refere ao aumento do próprio 
consumo, o que faz do homem/agressor um perigo à manutenção desta ordem e, consequentemente, um inimigo a ser punido severamente, a ser colocado no banco dos réus, sob a censura social. Noutras palavras, o homem agressor também é o homem perverso, aquele que escapa aos padrões de normalidade da sociedade contemporânea, a qual igualmente censura a mulher nervosa, a esposa frígida, a mãe indiferente, o jovem homossexual e a criança erotizada, todos incompatíveis com a manutenção econômica da célula familiar e que, por este motivo, devem ser normalizados, isto é, tratados ou punidos (FOUCAULT, 1988, p. 104).

\section{CONSIDERAÇÕES FINAIS}

Como analisado, o direito penal constitui-se como discurso viril, armado para a guerra, elaborado por homens, impregnado por construções sociais que o identificam com o masculino e que por anos serviram à naturalização e à manutenção da dominação masculina nas sociedades ocidentais. A sua utilização para combater a violência contra a mulher pode parecer eficiente num primeiro momento, quando promove o isolamento do homem agressor do seu convívio social, evitando de forma imediata a continuidade da violência. Todavia, este discurso não contribui significativamente para uma alteração significativa desta cultura machista que permeia nossas estruturas sociais objetivas e cognitivas, tal como demonstrado em pesquisas recentemente realizadas.

Ademais, a criminalização crescente das práticas de violência contra a mulher tem servido ao desenvolvimento da biopolítica neoliberal, que deslocou para o mercado - ou para aqueles que estão no controle do mercado - as decisões sobre a vida da população, sobre quem se deve fazer viver e quem se deve deixar morrer para o bem desta multiplicidade. Há algum tempo a famíliaempresa passou a ser essencial ao desenvolvimento do mercado e, consequentemente, do neoliberalismo, e aquele que se torna um obstáculo ao seu funcionamento, tal como o homem agressor, deve ser punido severamente, como propugnam a Lei Maria da Penha (BRASIL, 2006) e a Lei do Feminicídio (BRASIL, 2015).

Em síntese, o direito penal, como foi concebido pelos reformadores e depois operacionalizado pelos neoliberais, não é o discurso apto ao combate da violência contra a mulher. Ou seja, colocar o machismo no banco dos réus não diminui as agressões por razões de gênero. Acredita-se que o discurso da lei só poderá oferecer respostas eficazes a esse fenômeno ao se degenerar, ao se estabelecer a partir de um discurso que não seja masculino ou feminino, ao deixar para trás o binário homem-agressor/mulher-vítima, ao ter como pressuposto que todos os indivíduos 
sofrem os efeitos das construções sociais de gênero e sexo, ao se preocupar com a criação de instrumentos pedagógicos e de diálogo para a superação deste machismo naturalizado nas sociedades ocidentais. O discurso jurídico só servirá ao combate da violência contra a mulher quando deixar de ser pautado pela grade econômica, pelos interesses do mercado, quando se transformar num discurso de resistência, que não normaliza e não se deixa normalizar.

\section{REFERÊNCIAS}

AGAMBEN, Giorgio. Homo sacer: o poder soberano e a vida nua. Trad. Henrique Burigo. Belo Horizonte: EdUFMG, 2007.

ANDRADE, Vera R. Criminologia e feminismo: da mulher como vítima à mulher como de construção da cidadania. Sequência, v. 18, n. 35, Florianópolis: UFSC, p. 42-49, 1997.

BANDEIRA, Lourdes; MELO, Hildete P. de. Títulos e memórias do feminismo no Brasil. Brasília: SPM, 2010.

BECCARIA, Cesare. Dos delitos e das penas. Trad. Alexis Augusto Couto de Brito. São Paulo: QuartierLatin, 2005.

BENTHAM, Jeremy. O panóptico. Trad. Tomaz Tadeu da Silva. Belo Horizonte: Autêntica, 2000.

BOURDIEU, Pierre. A dominação masculina. Trad. Maria Helena Kühner. Rio de Janeiro: BestBolso, 2014.

O poder simbólico. Trad. Fernando Tomaz. Rio de Janeiro: Bertrand, 1989.

BORGES, Clara Maria Roman; OLIVEIRA, João Rafael de. A expansão do controle por meio das medidas cautelares pessoais diversas da prisão. Revista da Faculdade de Direito UFPR, v. 59, n. 3, p. 225-247, nov. 2014.

BUTLER, Judith. Problemas de gênero: feminismo e subversão da identidade. Trad. Renato Aguiar. Rio de Janeiro: Civilização Brasileira, 2003.

CALCIOLARI, Silvia; MONTEIRO, Luiz Carlos (Coautor). Ex-presos políticos e a memória social da tortura no Paraná (1964-1978). Curitiba: [Assembleia Legislativa do Paraná], 2006.

CAMPOS, Carmen Hein de; CARVALHO, Salo de. Tensões atuais entre a criminologia feminista e a criminologia crítica: a experiência brasileira. In: CAMPOS, Carmen Hein de (Org.). Lei Maria da Penha (comentada em uma perspectiva jurídico-feminista). Rio de Janeiro: Lumen Juris, 2011, p. 143-169.

CANCIO MELIÁ, Manuel. Direito Penal do Inimigo? In: JAKOBS, Gunther; CANCIO MELIÁ, Manuel. Direito penal do inimigo: noções e críticas. 3 ed. Porto Alegre: Livraria do Advogado, 2008. 
CHAUÍ, Marilena. Participando do debate sobre mulher e violência. In: CHAUÍ, Marilena; CARDOSO, Ruth; PAOLI, Maria Celia (Org.). Perspectivas antropológicas da mulher: sobre mulher e violência. Rio de Janeiro: Zahar, 1985. v. 4, p. 25-62.

DELEUZE, Gilles. Conversações. Trad. Peter Pál Pelbart, São Paulo: Ed. 34, 1992.

DUARTE, André. Foucault e as novas figuras da biopolítica: o fascismo contemporâneo. In: RAGO, Margareth; VEIGA-NETO, Alfredo (Org.). Para uma vida não fascista. Belo Horizonte: Autêntica, 2009.

EWALD, François. Foucault: A norma e o direito. Trad. António Fernando Cascais. Lisboa: Veja, 1993.

FONSECA, Márcio Alves da. Michel Foucault e o direito. São Paulo: Max Limonad, 2002.

FOUCAULT, Michel. A governamentalidade. In: FOUCAULT, Michel (Org.) Microfísica do poder. Trad. Roberto Machado, 13. ed. Rio de Janeiro: Graal, 1999.

A história da sexualidade I: a vontade de saber. Trad. Maria Thereza da Costa Albuquerque e J. A. Guilhon Albuquerque. 13. ed. Rio de Janeiro: Graal, 1988.

Aula de 14 de fevereiro de 1979. O nascimento da biopolítica: curso dado no Collège de France (1978-1979). Trad. Eduardo Brandão. São Paulo: Martins Fontes, 2008a, p. 179-219.

. Aula de 17 de março de 1976. Em defesa da sociedade. Trad. Maria Ermantina Galvão. São Paulo: Martins Fontes, 1999, p. 285-315.

. Aula de 21 de janeiro de 1976. Em defesa da sociedade. Trad. Maria Ermantina Galvão. São Paulo: Martins Fontes, 1999, p. 49-73.

. Aula de 21 de março de 1979. O nascimento da biopolítica: curso dado no Collège de France (1978-1979). Trad. Eduardo Brandão. São Paulo: Martins Fontes, 2008a, p. 329-363.

. Aula de 24 de janeiro de 1979. O nascimento da biopolítica: curso dado no Collège de France (1978-1979). Trad. Eduardo Brandão. São Paulo: Martins Fontes, 2008a, p. 71-101.

. La 'gouvernementalité'. Dits et Écrits. Org. Daniel Defert et François Ewald. Paris: Gallimard, 1994a, v. III.

. Segurança, território e população: curso dado no Collège de France (1977-1978). Trad. Eduardo Brandão. São Paulo: Martins Fontes, 2008b.

. Vigiar e punir: a história da violência nas prisões. Trad. Raquel Ramalhete. 11. ed. Petrópolis: Vozes, 1994b.

GOLDENBERG, Mirian. Mulheres e militantes. Revista de Estudos Feministas. v. 5; n. 2, p. 349365, 1997. 
GIANORDOLI-NASCIMENTO, Ingrid F.; TRINDADE, Zeidi A.; SANTOS, Maria de Fátima S. Mulheres e militância: encontros e confrontos durante a ditadura militar. Belo Horizonte: EdUFMG, 2012.

GREGORI, Maria Filomena. Cenas e queixas: mulheres e relações de violência. Novos Estudos, n. 23, Cebrap, São Paulo, p. 163-175, mar. 1999.

IZUMINO, Wânia Pasinato; SANTOS, Cecília Macdowell. Violência contra as mulheres e violência de gênero no Brasil. Revista Estudios Interdisciplinários de America Latina y El Caribe. Israel: Universidade de Tel Aviv, v. 1, n. 16, p. 147-164, 2005.

KARAM, Maria Lúcia. A esquerda punitiva. Discursos sediciosos: crime, direito e sociedade, ano 1, n. 1, p. 79-92, jan.-jun. 1996.

LOMBROSO, Cesare. O Homem delinquente. Trad. Sebastião José Roque. São Paulo: Ícone, 2013.

LUTZ, Bertha. 13 Princípios Básicos: sugestões ao ante-projeto da Constituição. Rio de Janeiro: FBPF, 1933.

MUCHAIL, Salma Tannus. O lugar das instituição na sociedade disciplinar. In: RIBEIRO, Renato Janine (Org.). Recordar Foucault. São Paulo: Brasiliense, 1986.

OJEDA, Igor; MERLINO, Tatiana. Direito à memória e à verdade: luta, substantivo feminino. São Paulo: Editora Caros Amigos, 2010.

PINTO, Celi Regina Jardim. Feminismo, história e poder. Revista Sociologia Política, Curitiba, v. 18, n. 36, p. 15-23, jun. 2010.

. Uma história do feminismo no Brasil. São Paulo: Fundação Perseu Abramo, 2003.

PRECIADO, Beatriz. Testo Yonqui. Madrid: Espasa, 2008.

RAMOS, Margarita Danielle. Reflexões sobre o processo histórico-discursivo do uso da legítima defesa da honra no Brasil e a construção das mulheres. Revista Estudos Feministas, v. 20 n. 1, Florianópolis, jan./abr., p. 53-73, 2012.

SAFFIOTI, Heleieth. A mulher na sociedade de classes: mito e realidade. 3. ed. São Paulo: Expressão Popular, 2013.

; ALMEIDA, Suely Souza de. A violência de gênero: poder e impotência. Rio de Janeiro: Revinter, 1995.

SARTI, Cynthia. O feminismo no Brasil: uma trajetória particular. Cadernos de Pesquisa, n. 64, São Paulo, p. 38-47, fev. 1988.

SCOTT, Joan W. A useful category of historical analysis. The American Historical Review, v. 91, n. 5, p. 1053-1075, dez. 1986. 
SOARES, Vera. Muitas faces do feminismo no Brasil. In: BORBA, Ângela; FARIA, Nalu; GODINHO, Tatau (Org.). Mulher e Política: Gênero e feminismo no Partido dos Trabalhadores. São Paulo: Editora Fundação Perseu Abramo, 1998.

SOUZA, Jessé. A ralé brasileira: quem é e como vive. Belo Horizonte: Editora UFMG, 2011.

SPAIN, Daphne. Gendered spaces. Chapel Hill: UNC, 1992.

ZAFFARONI, E. Raúl. O inimigo no direito penal. Trad. Sérgio Lamarão. 2. ed. Rio de Janeiro: Revan, 2007.

\section{DOCUMENTOS}

BRASIL. CNV. Relatório Final da Comissão Nacional da Verdade. Brasília: CNV, 2014. Disponível em: <http://www.cnv.gov.br>. Acesso em: 14 jul. 2015.

. Lei $n^{0}$ 11.340/06. Altera o Código de Processo Penal, o Código Penal e a Lei de Execução Penal; e dá outras providências. Diário Oficial da União, Brasília, DF, 8 de agosto de 2006. Disponível em: <http://www.planalto.gov.br/ccivil_03/_ato2004-2006/2006/lei/11340.htm>. Acesso em: 14 jul. 2015.

. Lei $n^{0}$ 13.104/15. Altera o art. 121 do Decreto-Lei $n^{0} 2.848$, de 7 de dezembro de 1940 Código Penal, e o art. $1^{\circ}$ da Lei ${ }^{0}{ }^{0}$ 8.072, de 25 de julho de 1990. Diário Oficial da União, Brasília, DF, 10 de março de 2015. Disponível em: <http://www.planalto.gov.br/ccivil_03/_ato20042006/2006/lei//11340.htm>. Acesso em: 14 jul. 2015.

CERQUEIRA, Daniel; MATOS, Mariana Vieira Martins; MARTINS, Ana Paula Antunes; PINTO JR, Jony. Avaliando a efetividade da Lei Maria da Penha (TD $n^{0}$ 2048). Rio de Janeiro/Brasília: IPEA, 2015. Disponível em: <http://goo.gl/w5jzUF>. Acesso em: 23 maio 2015.

OSÓRIO, Rafael Guerreiro; FONTOURA, Natália. Comunicado SIPS/2014. Tolerância social à violência contra as mulheres. Disponível em: <http://goo.gl/ddknmh>. Acesso em: 23 maio 2015.

LUTZ, Bertha. [Discurso] Diário Oficial do Poder Legislativo. 20.07.1936. Disponível em: <http://goo.gl/tmHqkh>. Acesso em: 12 maio 2015.

[Projeto de Lei $n^{0}$ 736/1937]. Exposição de motivos. Câmara dos Deputados. Comissão Estatuto da Mulher, 1937. Disponível em: <http://hs.unb.br/bertha/?series\&paged=2>. Acesso em: 12 maio 2015. 


\title{
MACHISMO IN THE DOCK \\ A CRITICAL FEMINIST ANALYSIS OF BRAZILIAN CRIMINAL POLICY CONCERNING THE COMBAT OF VIOLENCE AGAINST WOMEN
}

\begin{abstract}
The aim of this article is to critically analyze the feminist discourse that led to the recent enactment of Brazilian laws that increased the penalties for violence against women, in order to demonstrate that they cannot escape the cognitive traps established by male domination naturalized in Western societies and how they have served the development of neoliberal biopolitics.
\end{abstract}

KEYWORDS: Feminism. Gender-based violence. Maria da Penha Act. Femicide. Criminalization.

Recebido: 15 junho 2015

Aprovado: 20 julho 2015 